\title{
Detection and Possible Role of Proteasomes in the Bronchoalveolar Space of the Injured Lung
}

\author{
M. MAJETSCHAK ${ }^{1,2}$, L. T. SORELL ${ }^{2}$, T. PATRICELLI ${ }^{2}$, D. H. SEITZ ${ }^{3}$, M. W. KNÖFERL ${ }^{3}$ \\ ${ }^{1}$ The Burn and Shock Trauma Institute, Department of Surgery, Stritch School of Medicine, Loyola \\ University Chicago, USA ${ }^{2}$ DeWitt Daughtry Family Department of Surgery, Miller School of \\ Medicine, University of Miami, USA, ${ }^{3}$ Department of Trauma Surgery, University of Ulm, \\ Germany
}

Received February 12, 2008

Accepted May 20, 2008

On-line July 18, 2008

\section{Summary}

Recent observations suggest the presence of $20 \mathrm{~S}$ proteasomes (20S) in the lung epithelial lining fluid. However, the physiological relevance of $20 \mathrm{~S}$ in the alveolar space and possible contribution to disease processes are unknown. Thus, we evaluated whether extracellular proteasomes could have a pathophysiological role in the injured lung using a rat model of lung contusion (LC). Bronchoalveolar lavage fluids (BALF) were obtained at various time points for up to $168 \mathrm{~h}$ after LC or sham procedure. Enzyme activities, ELISA and Western blots indicated enzymatically active 20S, the 19S subunit Rpt5 and ubiquitin in BALF. 20S and ubiquitin increased significantly after LC, peaked at $24 \mathrm{~h}$ and normalized within $168 \mathrm{~h}$. $\mathrm{Mg}^{2+} / \mathrm{ATP}$-dependent peptidase activities were detectable 6-24 $\mathrm{h}$ after LC. BALF after LC also contained ubiquitin-protein-ligase activity. Addition of $\mathrm{Mg}^{2+} / \mathrm{ATP}$ to BALF after LC led to significant proteolysis and could be prevented with epoxomicin and EDTA. These data suggest for the first time that the $\mathrm{Mg}^{2+} / \mathrm{ATP}$-dependent $26 \mathrm{~S}$ proteasome complex exists outside the cell, is released into the lung epithelial lining fluid after LC and contributes to the proteolysis of the bulk of protein in the alveolar space of the injured lung. We infer that proteasome complexes may have a pathophysiological role during lung edema clearance.

\section{Key words}

26S proteasome $\bullet 20$ S core particle $\bullet$ 19S regulator complex • Ubiquitin • Ubiquitin-protein ligase

\section{Corresponding author}

M. Majetschak, The Burn and Shock Trauma Institute, Department of Surgery, Loyola University Chicago Stritch School of Medicine, 2160 S. First Avenue, Maywood, IL 60153, USA. Fax: $++1(708)$ 327 2813. E-mail: mmajetschak@lumc.edu

\section{Introduction}

The ubiquitin-proteasome-pathway (UPP) is the principal non-lysosomal proteolytic system in all eukaryotic cells. In this pathway, ubiquitin-protein ligase systems catalyze the covalent ligation of ubiquitin to intracellular proteins (Hershko and Ciechanover 1998). The ubiquitylated protein is then destined for degradation by the multicatalytic $26 \mathrm{~S}$ proteasome $(26 \mathrm{~S})$. The $26 \mathrm{~S}$ is formed from a cylinder-shaped multimeric protein complex referred to as the $20 \mathrm{~S}$ proteasome core particle (20S) and singly or doubly capped by a regulatory component termed the 19S regulator complex (19S), which confers $\mathrm{Mg}^{2+} / \mathrm{ATP}$-dependency and ubiquitylated substrate specificity. While $\mathrm{Mg}^{2+} / \mathrm{ATP}$ is required for assembly and function of the $26 \mathrm{~S}$ complex, the $20 \mathrm{~S}$ alone is involved in the degradation of misfolded and damaged proteins, independent of $\mathrm{Mg}^{2+} / \mathrm{ATP}$ or ubiquitylation (Hershko and Ciechanover 1998, Baumeister et al. 1998).

Some of the protein components of the UPP have also been identified in extracellular fluids, such as serum, cerebrospinal, epididymal or bronchoalveolar fluids (BALF) (Wada et al. 1993, Magi et al. 2005, Majetschak et al. 2003, 2005a, Zoeger et al. 2006, Bai et al. 2007, Baska et al. 2008, Sixt et al. 2007). While previous data suggest a pathophysiological role of free extracellular ubiquitin during inflammation (Kieffer et al. 2003, Majetschak et al. 2003, 2005b), the functional relevance of extracellular proteasomes, their natural protein substrates and possible contribution to disease 
processes are unknown.

As compared with healthy volunteers, circulating levels of ubiquitin and $20 \mathrm{~S}$ are significantly elevated in severely injured patients (Majetschak et al. 2003, Roth et al. 2005), but their possible alterations and function in the alveolar space of the injured lung have not been studied. Thus, using a well described model of lung contusion (LC) in rats, we evaluated whether increased release of UPP components into the alveolar space occurs after trauma and whether those components could play a pathophysiological role in the injured lung.

\section{Methods}

\section{Animal protocol}

All procedures were performed according to NIH Guidelines for the Use of Laboratory Animals and approved by the IACUC. LC was induced using a blast wave model, as described in detail previously (Jaffin et al. 1987, Knöferl et al. 2003). In brief, anesthetized (3\% servoflurane (Abbott, Wiesbaden, Germany), $97 \%$ oxygen, flow $0.8 \mathrm{l} / \mathrm{min}$ ) and spontaneously breathing male Sprague Dawley rats $(\mathrm{n}=50,250-275 \mathrm{~g}$, Charles River, Sulzfeld, Germany) were placed on an acrylic glass plate in supine position. A single blast wave (exposure distance: $2 \mathrm{~cm}$, peak pressure: 0.73 bar, duration: $3.4 \mathrm{~ms})$ centered on the thorax $(\mathrm{n}=25)$ was delivered using a blast wave generator (Jaffin et al. 1987). With this non-lethal model a bilateral LC is induced without additional injury to abdominal organs or bony structures of the chest (Knöferl et al. 2003). Sham animals $(\mathrm{n}=25)$ underwent the same procedures, but no blast wave was delivered. Animals were allowed to recover from anesthesia and then brought back to their cages with free access to food and water. To collect BALF, each five sham and LC animals were sacrificed by exsanguination (aortal puncture) under general anesthesia after $6 \mathrm{~h}, 12 \mathrm{~h}, 24 \mathrm{~h}, 48 \mathrm{~h}$ and $168 \mathrm{~h}$. The trachea was cannulated and lungs were lavaged twice with $5 \mathrm{ml}$ of ice cold PBS. The recovery was 3-4 $\mathrm{ml}$ per lavage. BALF were pooled, centrifuged $\left(16000 \times \mathrm{g}, 4{ }^{\circ} \mathrm{C}, 2 \mathrm{~min}\right)$ and supernatants stored at $-80^{\circ} \mathrm{C}$ until analyses.

\section{Ubiquitin ELISA}

Ubiquitin concentrations were quantified with a competitive ELISA, as described in detail previously (Majetschak et al. 2005a). Addition of purified hemoglobin to the assay did not affect measurements. The lower detection limit was $11 \mathrm{ng} / \mathrm{ml}$.

\section{S ELISA}

20S were quantified by ELISA, as described (Majetschak et al. 2008). The correlation coefficients for each standard curve were $\geq 0.98$. The lower detection limit was $15 \mathrm{ng} / \mathrm{ml}$.

\section{Peptidase assays}

Peptidase activities were measured employing the fluorogenic peptide substrates $N$-Suc-Leu-Leu-ValTyr-7-amino-4-methylcoumarin (chymotryptic-like, CTL) and Bz-Val-Gly-Arg-7-amino-4-methylcoumarin (tryptic-like, T-L; both from Biomol), as described (Majetschak et al. 2008). Reaction mixtures contained $1 \mathrm{mM}$ DTE, $2 \mathrm{mM}$ ATP, $5 \mathrm{mM} \mathrm{MgCl} 2,10 \mathrm{mM}$ Tris/HCl, $\mathrm{pH}$ 8.0, $100 \mu \mathrm{M}$ peptide substrate and $20 \mu \mathrm{l}$ BALF. Mixtures were incubated for $60 \mathrm{~min}$ at $37{ }^{\circ} \mathrm{C}$. Ethanol $(2: 1 \mathrm{v} / \mathrm{v})$ was added, mixtures placed on ice for $10 \mathrm{~min}$ and centrifuged $\left(16000 \times \mathrm{g}, 5{ }^{\circ} \mathrm{C}, 6 \mathrm{~min}\right)$. Supernatants were transferred into microplates (Corning, Acton, MA) and free 7-amino-4-methylcoumarin cleaved from the substrates measured in a fluorescence reader (FLX8000, Bio-Tek, Woburn, MA, $\lambda_{\text {excitation/emission }}=360 / 455 \mathrm{~nm}$ ) against standard curves of 7-amino-4-methylcoumarin (Sigma). To differentiate the proteasome from other peptidase activities, the $\mathrm{Mg}^{2+} / \mathrm{ATP}$-dependent and epoxomicin-sensitive proportions were determined by addition of $10 \mathrm{mM}$ EDTA and $7 \mu \mathrm{M}$ epoxomicin (Biomol) to the mixtures (Eytan et al. 1993, Meng et al. 1999). Proteasome peptidase activities were determined as mol of 7-amino-4-methylcoumarin cleaved per hour and $\mathrm{ml}$.

\section{Western blots}

Immunoblotting to ubiquitin and proteasome subunits was performed as described previously (Majetschak et al. 2003, 2005a, 2008, Patel et al. 2007, Patel and Majetschak 2007). In brief, BALF proteins were separated by SDS-PAGE (4-15\% gels, Bio-Rad, Hercules, CA), transferred to nitrocellulose membranes (Hybond-ECL, Amersham Biosciences) and probed with anti-ubiquitin (1:800, Sigma, St. Louis, MO) and a HRPlabeled secondary antibody (1:10000, Amersham Biosciences). Visualization and quantification of immunoreactive proteins were performed with chemiluminescence detection (Super-Signal, Pierce, Rockford, IL) using the ImageMaster system with the ImageQuant analysis software (Amersham Biosciences). For immunoblotting to proteasome subunits anti-20S "core" which has been shown to react with the $20 \mathrm{~S}$ subunits $\alpha 5, \alpha 7, \beta 1, \beta 5, \beta 5 \mathrm{i}, \beta 7$ (1:2000; Biomol, 
Plymouth Meeting, PA), anti-20S subunit $\beta 3$ and anti19S ATPase subunit Rpt5 (both 1:1000; Biomol) were used in combination with corresponding secondary HRPlabeled anti-mouse (Pierce) and anti-rabbit (Amersham), accordingly.

\section{Ubiquitylation assay}

Ubiquitin protein ligase activity was assessed as incorporation of biotinylated ubiquitin (ubiquitin ${ }_{b}$ ) into the sum of BALF proteins (Majetschak et al. 2008, Patel et al. 2007, Patel and Majetschak 2007). Incubation mixtures contained $1 \mathrm{mM}$ DTE, 0 or $2 \mathrm{mM} \mathrm{ATP,} 0$ or $5 \mathrm{mM} \mathrm{MgCl} 2,10 \mathrm{mM}$ Tris $/ \mathrm{HCl}, 10 \mu \mathrm{g} / \mathrm{ml}$ ubiquitin $_{\mathrm{b}}$ and $25 \mu \mathrm{l} \mathrm{BALF}$ at $\mathrm{pH}$ 8. Mixtures were incubated for $60 \mathrm{~min}$ at $37{ }^{\circ} \mathrm{C}$. After incubation, Laemmli sample buffer $(50 \% \mathrm{v} / \mathrm{v})$ was added and the mixtures were boiled for $5 \mathrm{~min}$, and then separated by SDS-PAGE. Immunoblotting was performed using a goat anti-biotin antibody conjugated to horseradish peroxidase (Sigma), as described.

\section{ATP assay}

ATP concentrations were determined with recombinant firefly luciferase and its substrate D-luciferin using a commercially available assay kit (Molecular Probes, Eugene, OR) according to the manufacturer's instructions. The lower detection limit was $15 \mathrm{nM}$.

\section{Detection of hemolysis}

Oxyhemoglobin and bilirubin levels were estimated spectrophotometrically according to (Cruickshank 2001, Majetschak et al. 2005a). For the detection of oxyhemoglobin absorption (A) was measured at $414 \mathrm{~nm}$. Bilirubin absorption was measured at $453 \mathrm{~nm}$ and $578 \mathrm{~nm}$. Bilirubin concentration (mM) was calculated as (A453 nm - A $578 \mathrm{~nm}) \times 23$, where $578 \mathrm{~nm}$ is the wavelength at which oxyhemoglobin has identical absorbance to its absorbance at $453 \mathrm{~nm}$, and 23 is the extinction coefficient for bilirubin at $453 \mathrm{~nm}$ (Cruickshank 2001).

\section{Other methods}

For trichloroacetic acid (TCA) precipitation of proteins, samples were mixed 1:1 (volume/volume) with $10 \%$ TCA, placed on ice for $30 \mathrm{~min}$ and centrifuged $(16000 \times \mathrm{g}, 20 \mathrm{~min})$. The pellet was resuspended in $0.1 \mathrm{~N}$ $\mathrm{NaOH}, 1 \%$ SDS. Protein was measured using a commercially available assay kit (Bio-Rad). SDS-gels were stained with Coomassie blue (Bio-Rad) and analyzed using the ImageMaster system and ImageQuant analysis software. After images were captured, pixel densities of each lane were plotted against the $\mathrm{Rf}$ ((distance of protein migration)/(distance of tracking dye migration)) value. Spline curves were calculated, normalized and plotted. For each gel the corresponding molecular masses were calculated using the Rf-values of protein standards (Precision Plus, Bio-Rad).

\section{Statistics}

Data are described as the mean \pm S.E.M. Paired and independent samples t-test and Spearman correlation coefficients $\left(\mathrm{r}_{\mathrm{s}}\right)$ were calculated with the SPSS-program (Chicago, IL). Spline curves were calculated with the GraphPad-Prism-program (GraphPad-Software, San Diego, CA). A two-tailed $\mathrm{p}<0.05$ was considered significant.

\section{Results}

Protein content averaged $1.3 \pm 0.16 \mathrm{mg} / \mathrm{ml}$ in BALF from control animals and did not show significant alterations during the observation period. Protein concentrations in BALF were significantly elevated between 6-48 h after LC (average: $4.6 \pm 0.5 \mathrm{mg} / \mathrm{ml}$ ) and returned to control values after $168 \mathrm{~h}(0.8 \pm 0.2 \mathrm{mg} / \mathrm{ml}$; Fig. 1A). There was noticeable hemolysis in BALF after LC. Oxyhemoglobin and bilirubin levels increased with peak levels at 24-48 $\mathrm{h}$ and normalized within $168 \mathrm{~h}$ (Fig. 1B/C). Ubiquitin was detectable in $40 \%$ of BALF after sham procedure and in all BALF after LC. 20S protein was detectable in $83 \%$ and $90 \%$ of BALF from controls and injured animals, respectively. Compared with BALF from control animals at corresponding time points, 20S and ubiquitin concentrations increased 5-10 fold in BALF after LC (Fig. 1 D/E). 20S and ubiquitin peaked at $24 \mathrm{~h}$ after LC (20S: $2397 \pm 71 \mathrm{ng} / \mathrm{ml}$; ubiquitin: $469 \pm 124 \mathrm{ng} / \mathrm{ml}$ ) and returned to control levels at $168 \mathrm{~h}$ (20S: $42 \pm 30 \mathrm{ng} / \mathrm{ml}$; ubiquitin: $31 \pm 6 \mathrm{ng} / \mathrm{ml}$ ). Western blots confirmed these findings (Fig. 1F) and showed that the signals for ubiquitin (lanes 1 and 2), 20S "core" subunits (lanes 3 and 4) and 20S subunit $\beta 3$ (lanes 5 and 6) were stronger in BALF $24 \mathrm{~h}$ after LC than after sham procedure. BALF probed also positive for the 19S ATPase subunit Rpt5, with stronger signals in BALF after LC (lanes 7 and 8).

After sham procedure, epoxomicin-sensitive chymotryptic-like activities were detectable in $96 \%$ and 

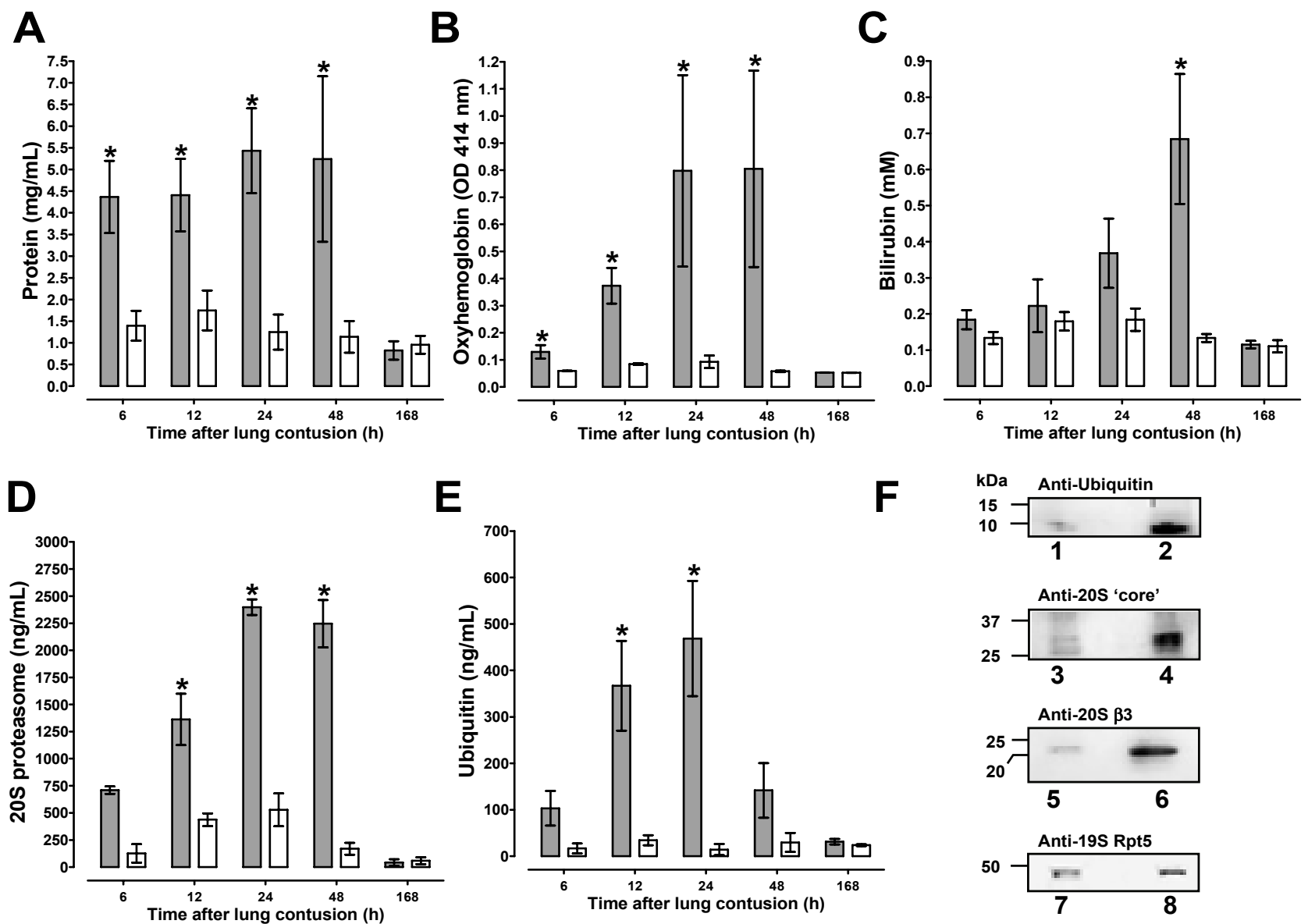

Fig. 1. BALF concentrations of $20 \mathrm{~S}$ proteasome core particles (20S) and ubiquitin are increased in BALF after lung contusion (LC). Measurements in BALF ( $n=5$ per group and time point). Data are mean \pm SEM. Open bars: Sham, gray bars: LC. $* p<0.05$ vs. sham. A. Protein (mg/ml). B. Oxyhemoglobin (OD $414 \mathrm{~nm})$. C. Bilirubin (mM). D. $20 \mathrm{~S}(\mathrm{ng} / \mathrm{ml})$. E. Ubiquitin (ng/ml). F. Western blotting to ubiquitin (lanes 1/2), 20S "core" subunits $\alpha 5,7, \beta 1,5,5 i, 7$ (lanes 3 and 4), 20S subunit $\beta 3$ (lanes 5 and 6) and 19S subunit Rpt5 (lanes 7 and 8). Each lane contains $20 \mu$ l of BALF. Lanes 1, 3, 5 and 7: Sham, 24 h. Lanes 2, 4, 6 and 8: LC, 24 h. Left: Migration positions of molecular mass standards.

Table 1. Correlation of $20 \mathrm{~S}$ and ubiquitin levels and proteasome peptidase activities with oxyhemoglobin and bilirubin levels in BALF.

\begin{tabular}{lll}
\hline & $\begin{array}{l}\text { Oxyhemoglobin } \\
(\mathbf{O D} \mathbf{4 1 4} \mathbf{~ n m})\end{array}$ & $\begin{array}{l}\text { Bilirubin } \\
\mathbf{( m M )}\end{array}$ \\
\hline 20S proteasome $(\mathrm{ng} / \mathrm{ml})$ & $0.668(<0.001)$ & $0.680(<0.001)$ \\
Ubiquitin $(\mathrm{ng} / \mathrm{ml})$ & $0.813(<0.001)$ & $0.368(0.017)$ \\
$C T-L(\mathrm{pmol} / \mathrm{h} / \mathrm{ml})$ & $0.768(<0.001)$ & $0.413(0.006)$ \\
$T-L(\mathrm{pmol} / \mathrm{h} / \mathrm{ml})$ & $0.634(<0.001)$ & $0.384(0.012)$ \\
\hline
\end{tabular}

Data are Speaman correlation coefficient $r_{s}$ with the level of statistical significance in parentheses. CT-L: Chymotryptic-like proteasome peptidase activity (epoxomicin-sensitive proportion). T-L: Tryptic-like proteasome peptidase activity (epoxomicin-sensitive proportion).

epoxomicin-sensitive tryptic-like activities in $28 \%$ of all specimens, and in $100 \%$ and $60 \%$ after LC, respectively. Changes in epoxomicin-sensitive chymotryptic- and tryptic-like peptidase activities paralleled changes in $20 \mathrm{~S}$ protein content (Fig. 2A/B). Compared with sham controls, epoxomicin sensitive chymotryptic-like activities were 22-fold and tryptic-like activities 79-fold elevated in BALF obtained $24 \mathrm{~h}$ after LC. Ubiquitin and $20 \mathrm{~S}$ concentrations as well as chymotryptic- and trypticlike proteasome activities correlated significantly positive with oxyhemoglobin and bilirubin levels (Table 1).

Because the immunoblotting experiments 
A

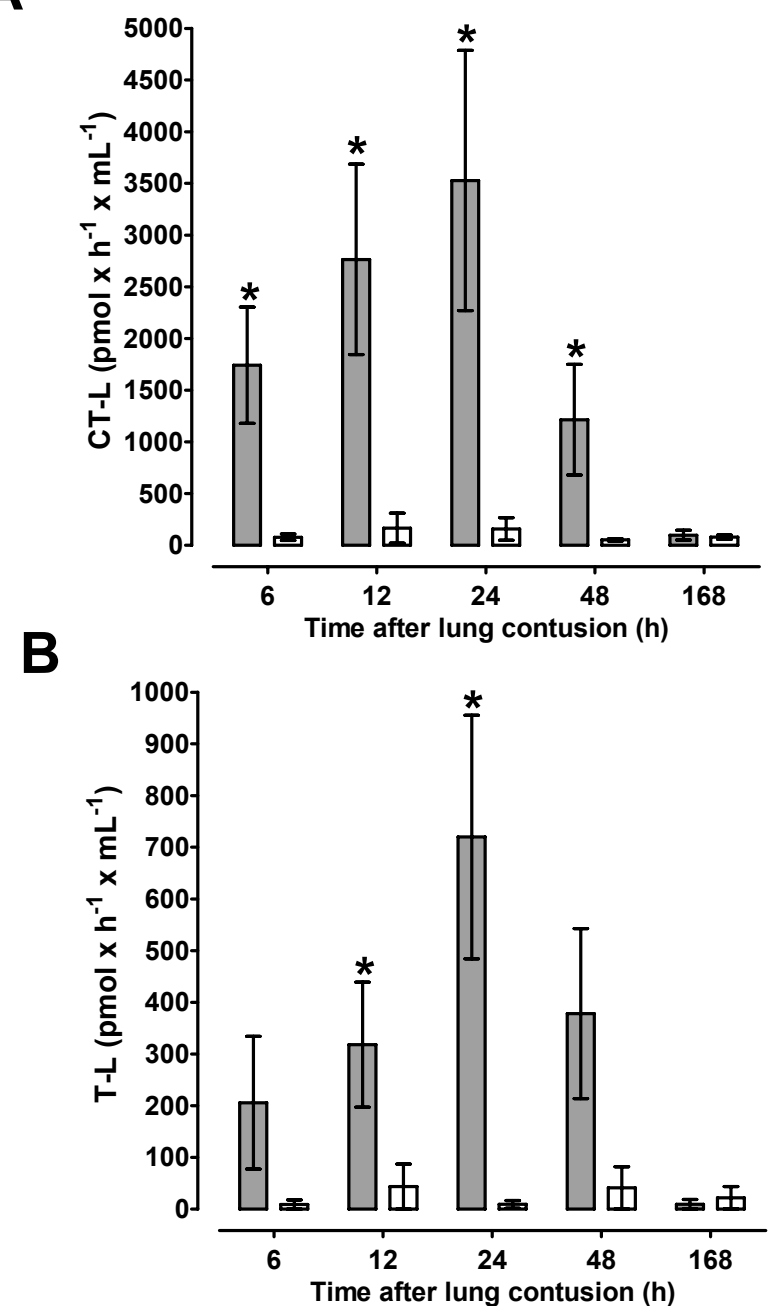

Fig. 2. Proteasome peptidase activities are increased in BALF after lung contusion (LC). Chymotryptic-like (CT-L; A) and tryptic-like ( $\mathrm{T}-\mathrm{L} ; \mathrm{B})$ proteasome peptidase activities in BALF (epoxomicin-sensitive proportions; $\mathrm{n}=5$ per group and time point). Open bars: Sham; grey bars: LC. Data are mean \pm SEM. $* \mathrm{p}<0.05$ vs. sham.

suggested that $19 \mathrm{~S}$ could also be present in BALF, we tested for $\mathrm{ATP} / \mathrm{Mg}^{2+}$-dependence of the peptidase activities to discriminate the ATP/ $\mathrm{Mg}^{2+}$ dependent $26 \mathrm{~S}$ complex. ATP-dependent activity was not detectable in BALF after sham procedure. In contrast, peptidase activities in BALF that was obtained between 6-24 $\mathrm{h}$ after CT were higher when assayed in the presence of ATP $/ \mathrm{Mg}^{2+}$ than in the presence of ATP $/ \mathrm{Mg}^{2+}$ and EDTA (Fig. 3A/C). The ATP-activity ratio (activities in the presence of $\mathrm{ATP} / \mathrm{Mg}^{2+} /$ activity in the presence of $\mathrm{ATP} / \mathrm{Mg}^{2+}$ and EDTA) of the individual samples reached 2.6 \pm 0.1 (chymotryptic-like, Fig. 3B) and $2.8 \pm 0.3$ (trypticlike, Fig. 3D) at $12 \mathrm{~h}$ after LC and returned to ATP independency (ATP ratio $\approx 1$ ) at later time points.

We further explored the possibility that ubiquitin protein ligase activity is detectable in BALF after LC. As shown in Figure 4A, incubation of BALF with ubiquitin led to newly formed ubiquitin ${ }_{b}$ protein conjugates (Fig. $4 \mathrm{~A}$, arrows $\mathrm{a} / \mathrm{b}$ ) and ubiquitylation was enhanced in the presence of ATP $/ \mathrm{Mg}^{2+}$ (pixel density: arrow a: lane $1-$ 342 , lane $2-1988$, lane $3-2791$; arrow b: lane $1-554$, lane $2-606$, lane $3-1214$ ).

ATP was not detectable in any of the BALF (not shown). The TCA precipitated protein content remained constant when BALF obtained 12-48 h after LC were incubated for $15 \mathrm{~h}$ at $37^{\circ} \mathrm{C}$ and decreased by $46 \pm 3 \%$ $(\mathrm{p}<0.001)$ when specimens were supplemented with $\mathrm{ATP} / \mathrm{Mg}^{2+}$ (Fig. 4B). The average BALF protein concentration in these specimens was $5.8 \mathrm{mg} / \mathrm{ml}$ and the degradation rate in the presence of ATP $/ \mathrm{Mg}^{2+}$ $125 \pm 19 \mu \mathrm{g} / \mathrm{ml} / \mathrm{h}$. ATP $/ \mathrm{Mg}^{2+}$-induced proteolysis could be inhibited by EDTA and epoxomicin. Supplementation of BALF with ATP $/ \mathrm{Mg}^{2+}$ and ubiquitin did not increase $\mathrm{ATP} / \mathrm{Mg}^{2+}$-induced protein degradation.

To obtain initial information on the natural substrates of the $\mathrm{ATP} / \mathrm{Mg}^{2+}$-dependent proteolytic activity, BALF were incubated as described before, equal protein amounts were separated by SDS-PAGE and the molecular mass profiles were analyzed. Figure $4 \mathrm{C}$ shows a typical Coomassie stained SDS-gel and Figure 4D depicts the average molecular mass profiles from three independent experiments. The protein pattern shifted towards the lower molecular mass range after incubation without exogenous ATP/ $\mathrm{Mg}^{2+}$ (Fig. 4C, lanes 2 and 3). Compared with BALF that were incubated without ATP $/ \mathrm{Mg}^{2+}$ (Fig. 4D, black line), addition of ATP $/ \mathrm{Mg}^{2+}$ led to a decrease of proteins in the range of $37-100 \mathrm{kDa}$ and an increase in low molecular mass proteins ( $\leq 10 \mathrm{kDa}$; Fig. 4C, lane 4; Fig. 4D, red line). This could be prevented with epoxomicin (Fig. 4C, lane 6; Fig. 4D, green line). Addition of EDTA (Fig. 4C, lane 5; Fig. 4D, blue line) also prevented ATP/ $\mathrm{Mg}^{2+}$-induced changes. As compared with BALF incubated with and without $\mathrm{Mg}^{2+} / \mathrm{ATP}$, addition of EDTA resulted in a protein pattern that resembled the protein pattern in BALF preincubation more closely.

\section{Discussion}

In the present study we show for the first time that UPP components are released into the bronchoalveolar space of the injured lung and provide initial experimental evidence for a functional role of extracellular proteasome complexes. First, we detected 
A

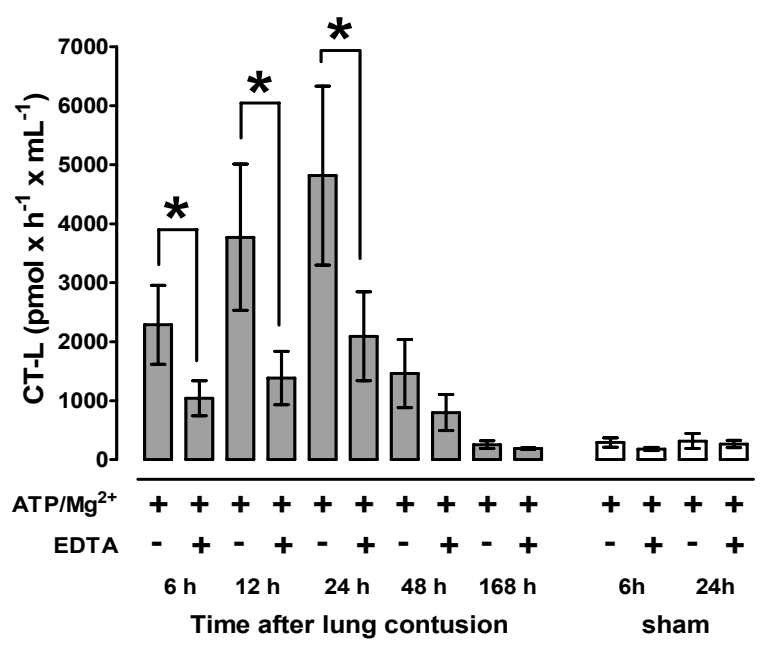

C

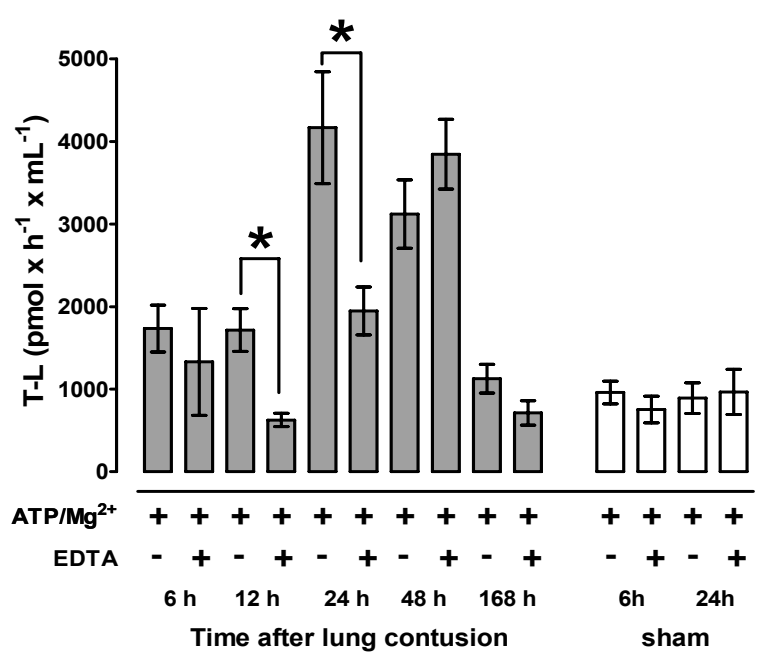

B

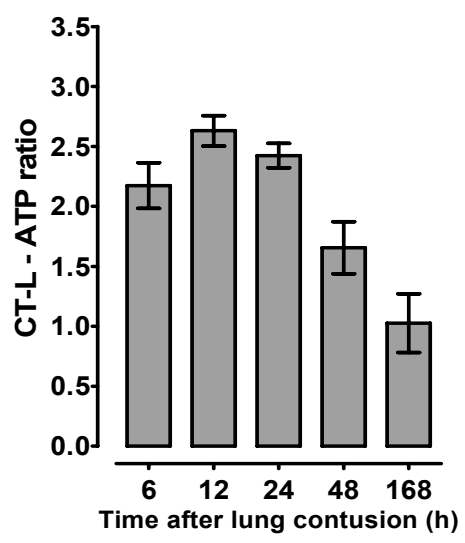

D

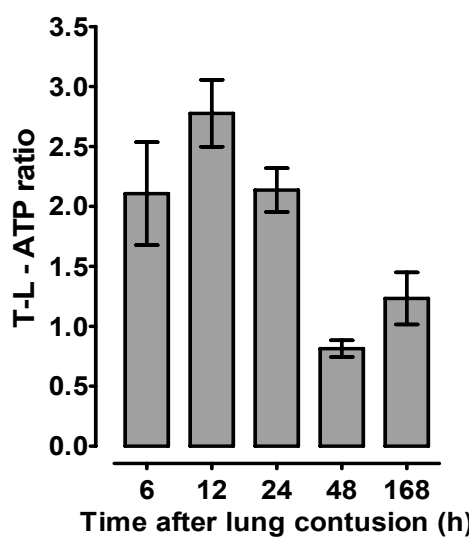

Fig. 3. $A T P / \mathrm{Mg}^{2+}$-dependent peptidase activities are detectable in BALF after lung contusion (LC). A and C: Chymotryptic-like (CT-L; A.) and tryptic-like $(\mathrm{T}-\mathrm{L} ; \mathbf{C})$ peptidase activities measured with $\left(\mathrm{ATP} / \mathrm{Mg}^{2+}+, \mathrm{EDTA}-\right)$ and without ATP/Mg ${ }^{2+}\left(\mathrm{ATP} / \mathrm{Mg}^{2+}+, \mathrm{EDTA}+\right) . \mathrm{n}=5$ per group and time point. Open bars: Sham. Grey bars: LC. Data are mean \pm SEM. $* p<0.05$ vs. measurements in the absence of ATP $/ \mathrm{Mg}^{2+}$. B and D: ATP-activity ratios (activities in the presence of ATP/ $\mathrm{Mg}^{2+} /$ activity in the presence of ATP/Mg ${ }^{2+}$ and EDTA) of the chymotryptic-like (B) and tryptic-like (D) peptidase activities measured in the individual BALF after LC.

significantly increased concentrations of ubiquitin and $20 \mathrm{~S}$ in BALF after LC. Second, BALF probed positive for the 19S ATPase subunit Rpt5. Third, ATP/Mg ${ }^{2+}$ dependent and epoxomicin-sensitive peptidase activities were present in BALF after LC. Fourth, addition of $\mathrm{ATP} / \mathrm{Mg}^{2+}$ to BALF obtained after LC induced proteolysis of endogenous BALF proteins. Fifth, ATP $/ \mathrm{Mg}^{2+}$-induced proteolysis in BALF could be inhibited by EDTA and by the specific proteasome inhibitor epoxomicin.

The ELISA measurements, Western blots and peptidase activity measurements confirmed the presence of ubiquitin and enzymatically active proteasomes in BALF (Magi et al. 2005, Bai et al. 2007, Sixt et al. 2007) and showed consistently that their concentrations in
BALF are significantly increased after LC. As expected, BALF protein content was also significantly elevated after LC, indicating that the blast wave injury induced relevant post-traumatic capillary leakage. The finding that ubiquitin and 20S levels did not parallel total BALF protein content after CT argues against their origin from the systemic circulation. Their positive correlations with parameters of hemolysis point towards erythrocytes as one cellular origin after LC.

It has been shown previously that the $19 \mathrm{~S}$ regulator complex can be dissociated into lid- and basesubcomplexes and intact 19S lid subcomplexes have been isolated from erythrocytes, thus suggesting that preassembled 19S subcomplexes exist in a free form (Glickman et al. 1998, Henke et al. 1999, Braun et al. 
A

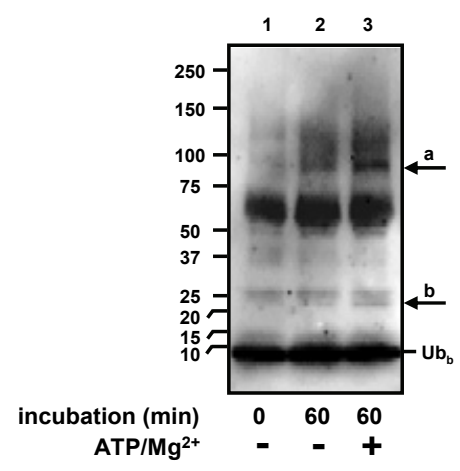

B

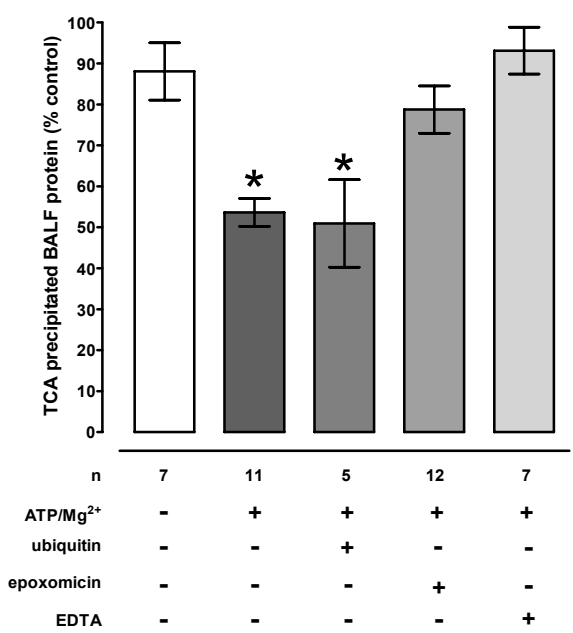

C

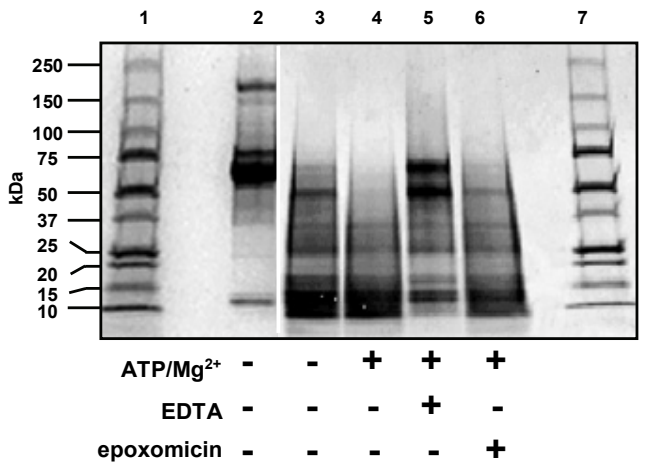

D

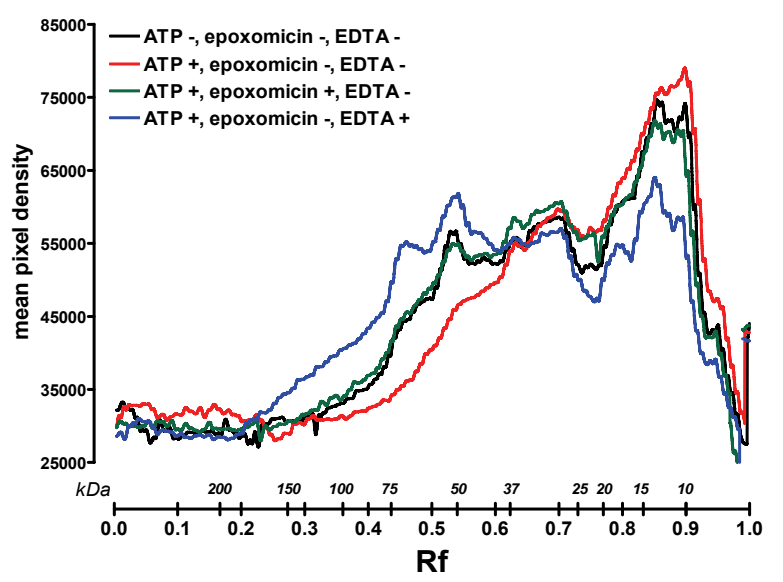

Fig. 4 A. Detection of ubiquitin protein ligase activity in BALF $24 \mathrm{~h}$ after lung contusion (LC). Left: Migration position of molecular mass standards. Lane 1: Incubation $0 \mathrm{~min}$, no ATP/ $\mathrm{Mg}^{2+}$. Lane 2: Incubation $60 \mathrm{~min}$, no ATP/Mg ${ }^{2+}$. Lane 3: Incubation $60 \mathrm{~min}$, with $2 \mathrm{mM}$ ATP/ $5 \mathrm{mM} \mathrm{Mg}^{2+}$. The arrows mark newly formed ubiquitin ${ }_{b}$-protein conjugates. B. ATP/Mg ${ }^{2+}$ supplementation of BALF obtained after LC induces proteolysis of natural BALF proteins that can be inhibited by the specific proteasome inhibitor epoxomicin. TCA-precipitated protein content in BALF incubated for $15 \mathrm{~h}$ at $37^{\circ} \mathrm{C}$ with or without $2 \mathrm{mM} \mathrm{ATP} / 5 \mathrm{mM} \mathrm{Mg}{ }^{2+}\left(\mathrm{ATP} / \mathrm{Mg}^{2+}\right)$, ubiquitin $(1 \mu \mathrm{g} / \mathrm{ml})$, epoxomicin $(7 \mu \mathrm{M})$ and EDTA $(10 \mathrm{mM})$. Protein content is expressed as \% preincubation. BALF were obtained $12-48 \mathrm{~h}$ after CT. Data are mean \pm SEM. * $p<0.05$ vs. pre-incubation. The number of experiments $(n)$ and incubation conditions are shown. C. Typical Coomassie stained SDS-gel with BALF obtained $24 \mathrm{~h}$ after LC incubated as described in B. Lanes 2-6 contain $20 \mu \mathrm{g}$ of protein. Lanes 1-2 and 3-7 were run on separate gels. Lanes 1/7: Protein standards. Lane 2: BALF, no incubation. Lanes 3-6: same BALF as in lane 2 after $15 \mathrm{~h}$ of incubation at $37{ }^{\circ} \mathrm{C}$ with or without $2 \mathrm{mM}$ ATP/ $5 \mathrm{mM} \mathrm{Mg}{ }^{2+}\left(\mathrm{ATP} / \mathrm{Mg}^{2+}\right)$, epoxomicin $(7 \mu \mathrm{M})$ and EDTA $(10 \mathrm{mM})$. D. Molecular mass profiles of BALF proteins incubated as described in B/C. The lines represent mean pixel densities from three independent experiments. The abscissa shows Rf values and corresponding molecular masses.

1999). Furthermore, it was shown that $19 \mathrm{~S}$ and $20 \mathrm{~S}$ can be released from $26 \mathrm{~S}$ proteasomes by ATP depletion and that re-addition of ATP leads to the reformation of $26 \mathrm{~S}$ proteasomes (Eytan et al. 1993, Peters et al. 1994). These data along with the findings from the present study suggest that $26 \mathrm{~S}$ complexes reassemble in BALF obtained after LC if ATP/ $\mathrm{Mg}^{2+}$ is present.

Although the 19S ATPase subunit Rpt5 was also detectable in BALF after sham procedure, we were unable to demonstrate ATP $/ \mathrm{Mg}^{2+}$-dependent peptidase activities in these BALF specimens. Similarly, Sixt et al. (2007) could not detect ATP/ $\mathrm{Mg}^{2+}$-dependent proteolysis of chemically modified and denatured bovine serum albumin in BALF from patients without lung pathologies.
There are several possible explanations for these observations. Besides the possibility that ATP/ $\mathrm{Mg}^{2+}-$ dependent enzyme activities in BALF from patients without lung pathologies (Sixt et al. 2007) or in BALF obtained after sham procedure in the present study were simply below the detection limit of the assays, artificial test substrates may not accurately reflect the enzymatic properties of proteasome complexes for natural protein substrates. On the other hand, the volume of the lung epithelial lining fluid is extremely small when compared with the volume of the BALF, the recovery of its chemical components may vary largely, and ectonucleotidases and their soluble forms are widely distributed (Stephens et al. 1996, Zimmermann 2000). 
Thus, it was not surprising that ATP concentrations in BALF were below the detection limit. As a consequence, $19 \mathrm{~S}$ and $20 \mathrm{~S}$ would be released from $26 \mathrm{~S}$ complexes in BALF (Eytan et al. 1993) and it is conceivable that reassembly of $26 \mathrm{~S}$ complexes requires additional protein factors which may not reach sufficient concentrations in BALF from sham controls, such as Hsp90 or Ecm29 (Imai et al. 2003, Gorbea et al. 2004). The finding that Hsp90 has already been identified in BALF strengthens this hypothesis (Sixt et al. 2007).

Nevertheless, it is well established that physiologically relevant concentrations of ATP are released into the extracellular space under various conditions, including tissue damage, low oxygen tension or inflammation (Kerkweg and de Groot 2005, Idzko et al. 2007, Sprague et al. 2007). Thus, the results of the present study imply the presence of ATP/ $\mathrm{Mg}^{2+}$-dependent $26 \mathrm{~S}$ proteasomes in the alveolar space of the injured lung.

Incubation of BALF in the absence of ATP/ $\mathrm{Mg}^{2+}$ led to a shift of the molecular mass distribution of BALF proteins towards the lower molecular mass range, while protein amounts after TCA precipitation remained constant. This finding is consistent with spontaneous and non-proteasomal breakdown of proteins into larger fragments without processing of oligopeptides, which are known to be produced by the proteasome (Greenberg and Shipe 1978, Hershko and Ciechanover 1998). The detection of an ATP/ $\mathrm{Mg}^{2+}$-dependent decrease in TCAprecipitated BALF protein content, the proteolytic cleavage rate for proteins with molecular masses between 37-100 $\mathrm{kDa}$ and the findings that EDTA and epoxomicin consistently abolished ATP/ $\mathrm{Mg}^{2+}$-induced proteolysis in BALF quantitatively and prevented the ATP/ $\mathrm{Mg}^{2+}$ induced shift of BALF proteins towards the lower molecular mass range, strongly suggest the presence and a functional role of $26 \mathrm{~S}$ complexes in the alveolar space of the injured lung. In addition, it should be noted that the protein pattern in BALF after incubation with $2 \mathrm{mM}$ ATP, $5 \mathrm{mM} \mathrm{Mg}^{2+}, 10 \mathrm{mM}$ EDTA was more similar to its preincubation protein pattern than to the resulting protein pattern after incubation without addition of ATP, $\mathrm{Mg}^{2+}$ and EDTA. This observation could point towards neutralization of the effects of divalent metal ions on protein structure and thermal stability by EDTA (Sissi et al. 2005).

Along with the detection of ubiquitin protein ligase activity in BALF after LC the findings of the present study open up the possibility that the entire ubiquitin-proteasome-pathway could be involved in processing of proteins in the alveolar space. The observation that addition of ubiquitin did not increase the $\mathrm{ATP} / \mathrm{Mg}^{2+}$-dependent proteolytic activity is not contradictive since the concentrations of endogenous ubiquitin in the incubation mixtures were at least 4-fold above the $\mathrm{K}_{\mathrm{m}}$ for ubiquitin protein ligase systems (Majetschak et al. 1998).

Taken together, the present study provides further evidence for the novel concept that the ubiquitinproteasome-pathway exists in the extracellular space (Baska et al. 2008). Our data suggest for the first time that $26 \mathrm{~S}$ proteasome complexes are present outside the cell and contribute significantly to the degradation of the bulk of endogenous proteins in the alveolar space of the injured lung. Based on these findings, we conclude a pathophysiologial role of proteasomes during lung edema clearance. Nevertheless, the clinical relevance of these findings remains to be determined since proteasome release into the alveolar space could also be harmful if proteins such as surfactant proteins are among its natural substrates.

\section{Conflict of Interest}

There is no conflict of interest.

\section{Acknowledgements}

We thank Lissette T. Novar for excellent technical help. This research was supported by grants DFG MA2474/22, KN475/3-2 and \#6123-1035-00-B contract \#W81XWH-05-1-0585 from the USAMRAA.

\section{References}

BAI Y, GALETSKIY D, DAMOC E, RIPPER J, WOISCHNIK M, GRIESE M, LIU Z, LIU S, PRZYBYLSKI M: Lung alveolar proteomics of bronchoalveolar lavage from a pulmonary alveolar proteinosis patient using highresolution FTICR mass spectrometry. Anal Bioanal Chem 389: 1075-1085, 2007.

BASKA KM, MANANDHAR G, FENG D, AGCA Y, TENGOWSKI MW, SUTOVSKY M, YI YJ, SUTOVSKY P: Mechanism of extracellular ubiquitination in the mammalian epididymis. J Cell Physiol 215: 684-696, 2008. 
BAUMEISTER W, WALZ J, ZÜHL F, SEEMÜLLER E: The Proteasome: paradigm of a self-compartmentalizing protease. Cell 92: 367-380, 1998.

BRAUN BC, GLICKMAN M, KRAFT R, DAHLMANN B, KLOETZEL PM, FINLEY D, SCHMIDT M: The base of the proteasome regulatory particle exhibits chaperone-like activity. Nat Cell Biol 1: 221-226, 1999.

CRUICKSHANK AM: CSF spectrophotometry in the diagnosis of subarachnoid haemorrhage. J Clin Pathol 54: 827830, 2001.

EYTAN E, ARMON T, HELLER H, BECK S, HERSHKO A: Ubiquitin C-terminal hydrolase activity associated with the $26 \mathrm{~S}$ protease complex. J Biol Chem 268: 4668-4674, 1993.

GLICKMAN MH, RUBIN DM, COUX O, WEFES I, PFEIFER G, CJEKA Z, BAUMEISTER W, FRIED VA, FINLEY D: A subcomplex of the proteasome regulatory particle required for ubiquitin conjugate degradation and related to the COP9-signalosome and eIF3. Cell 94: 615-623, 1998.

GORBEA C, GOELLNER GM, TETER K, HOLMES RK, RECHSTEINER M: Characterization of mammalian Ecm29, a $26 \mathrm{~S}$ proteasome-associated protein that localizes to the nucleus and membrane vesicles. $J$ Biol Chem 279: 54849-54861, 2004.

GREENBERG NA, SHIPE WF: Comparison of the abilities of tricloroacetic, picric, sulfosalicylic, and tungstic acids to precipitate protein hydrolysates and proteins. $J$ Food Sci 44: 735-737, 1978.

HENKE W, FERRELL K, BECH-OTSCHIR D, SEEGER M, SCHADE R, JUNGBLUT P, NAUMANN M, DUBIEL W: Comparison of human COP9 signalsome and 26S proteasome lid. Mol Biol Rep 26: 29-34, 1999.

HERSHKO A, CIECHANOVER A: The ubiquitin system. Annu Rev Biochem 67: 425-479, 1998.

IDZKO M, HAMMAD H, VAN NIMWEGEN M, KOOL M, WILLART MA, MUSKENS F, HOOGSTEDEN HC, LUTTMANN W, FERRARI D, DIVIRGILIO F, VIRCHOW JR. JC, LAMBRECHT BN: Extracellular ATP triggers and maintains asthmatic airway inflammation by activating dendritic cells. Nat Med 13: 913-919, 2007.

IMAI J, MARUYA M, YASHIRODA H, YAHARA I, TANAKA K: The molecular chaperone Hsp90 plays a role in the assembly and maintenance of the 26S proteasome. EMBO $J$ 22: 3557-35567, 2003.

JAFFIN JH, MCKINNEY L, KINNEY RC, CUNNINGHAM AJ, MORITZ DM, KRAIMER JM, GRAEBER GM, MOE JB, SALANDER JM, HARMON JW: A laboratory model for studying blast overpressure injury. J Trauma 27: 349-356, 1987.

KERKWEG U, DE GROOT H: ATP-induced calcium increase as a potential first signal in mechanical tissue trauma. A laser scanning microscopic study on cultured mouse skeletal myocytes. Shock 24: 440-446, 2005.

KIEFFER AE, GOUMON Y, RUH O, CHASSEROT-GOLAZ S, NULLANS G, GASNIER C, AUNIS D, METZBOUTIGUE MH: The N- and C-terminal fragments of ubiquitin are important for the antimicrobial activities. FASEB J 17: 776-778, 2003.

KNÖFERL MW, LIENER UC, SEITZ DH, PERL M, BRÜCKNER UB, KINZL L, GEBHARD F: Cardiopulmonary, histological, and inflammatory alterations after lung contusion in a novel mouse model of blunt chest trauma. Shock 19: 519-525, 2003.

MAGI B, BARGAGLI E, BINI L, ROTTOLI P: Cytokine profile and proteome analysis in bronchoalveolar lavage of patients with sarcoidosis, pulmonary fibrosis associated with systemic sclerosis and idiopathic pulmonary fibrosis. Proteomics 5: 1423-1430, 2005.

MAJETSCHAK M, LAUB M, KLOCKE C, STEPPUHN JA, JENNISSEN HP: The ubiquityl-calmodulin synthetase system from rabbit reticulocytes: isolation of the calmodulin-binding second component and enzymatic properties. Eur J Biochem 255: 492-500, 1998.

MAJETSCHAK M, KREHMEIER U, BARDENHEUER M, DENZ C, QUINTEL M, VOGGENREITER G, OBERTACKE U: Extracellular ubiquitin inhibits the TNF $\alpha$ response to endotoxin in peripheral blood mononuclear cells and regulates endotoxin hyporesponsiveness in critical illness. Blood 101: 1882-1890, 2003.

MAJETSCHAK M, KING DR, KREHMEIER U, BUSBY LT, THOME S, VAJKOCZY S, PROCTOR KG: Ubiquitin immunoreactivity in cerebrospinal fluid after traumatic brain injury: Clinical and experimental findings. Crit Care Med 33: 1589-1594, 2005a.

MAJETSCHAK M, PONELIES N, HIRSCH T: Targeting the monocytic ubiquitin system with extracellular ubiquitin. Immunol Cell Biol 84: 59-65, 2005b. 
MAJETSCHAK M, PATEL MB, LIOTTA C, SORELL LT, LI S, PHAM SM: Cardiac proteasome dysfunction during cold ischemic storage and reperfusion in a murine heart transplantation model. Biochem Biophys Res Commun 365: 882-888, 2008.

MENG L, MOHAN R, KWOK BH, ELOFSSON M, SIN N, CREWS CM: Epoxomicin, a potent and selective proteasome inhibitor, exhibits in vivo antiinflammatory activity. Proc Natl Acad Sci USA 96: 10403-10408, 1999.

PATEL MB, EARLE SA, MAJETSCHAK M: Dynamics of tissue ubiquitin pools and ubiquitin-proteasome pathway component activities during the systemic response to traumatic shock. Physiol Res. 56: 547-557, 2007.

PATEL MB, MAJETSCHAK M: Distribution and interrelationship of ubiquitin proteasome pathway component activities and ubiquitin pools in various porcine tissues. Physiol Res. 56: 341-350, 2007.

PETERS JM, FRANKE WW, KLEINSCHMIDT JA: Distinct $19 \mathrm{~S}$ and $20 \mathrm{~S}$ subcomplexes of the $26 \mathrm{~S}$ proteasome and their distribution in the nucleus and the cytoplasm. J Biol Chem 269: 7709-7718, 1994.

ROTH GA, MOSER B, KRENN C, ROTH-WALTER F, HETZ H, RICHTER S, BRUNNER M, JENSEN-JAROLIM E, WOLNER E, HOETZENECKER K, BOLTZ-NITULESCU G, ANKERSMIT HJ: Heightened levels of circulating 20S proteasome in critically ill patients. Eur J Clin Invest 35: 399-403, 2005.

SISSI C, MARANGON E, CHEMELLO A, NOBLE CG, MAXWELL A, PALUMBO M: The effects of metal ions on the structure and stability of the DNA gyrase B protein. J Mol Biol 353: 1152-1160, 2005.

SIXT SU, BEIDERLINDEN M, JENNISSEN HP, PETERS J: Extracellular proteasome in the human alveolar space: a new housekeeping enzyme? Am J Physiol 292: L1280-L1288, 2007.

SPRAGUE RS, STEPHENSON AH, ELLSWORTH ML: Red not dead: signaling in and from erythrocytes. Trends Endocrinol Metab 18: 350-355, 2007.

STEPHENS RH, BENJAMIN AR, WALTERS DV: Volume and protein concentration of epithelial lining liquid in perfused in situ postnatal sheep lungs. J Appl Physiol 80: 1911-1920, 1996.

WADA M, KOSAKA M, SAITO S, SANO T, TANAKA K, ICHIHARA A: Serum concentration and localization in tumor cells of proteasomes in patients with hematologic malignancy and their pathophysiologic significance. J Lab Clin Med 121: 215-223, 1993.

ZIMMERMANN H: Extracellular metabolism of ATP and other nucleotides. Naunyn-Schmiedeberg's Arch Pharmacol 362: 299-309, 2000.

ZOEGER A, BLAU M, EGERER K, FEIST E, DAHLMANN B: Circulating proteasomes are functional and have a subtype pattern distinct from 20S proteasomes in major blood cells. Clin Chem 52: 2079-2086, 2006. 